\title{
Optimization of extraction conditions of Corni Fructus for functional materialization
}

\author{
Chang-Jae Kang ${ }^{1}$, Gi-Un Seong ${ }^{1}$, Shin-Kyo Chung ${ }^{1,2 *}$ \\ ${ }^{1}$ School of Food Science and Biotechnology, Kyungpook National University, Daegu 41566, Korea \\ ${ }^{2}$ Food and Bio-industry Research Institute, Kyungpook National University, Daegu 41566, Korea
}

\section{산수유(Corni Fructus)의 기능성 소재화를 위한 적정 추출 조건}

\author{
강창재 $^{1} \cdot$ 성기운 $^{1} \cdot$ 정신교 ${ }^{1,2 *}$ \\ ${ }^{1}$ 경북대학교 식품공학부, ${ }^{2}$ 경북대학교 식품생물산업연구소
}

\begin{abstract}
In order to determine a proper extraction condition of Corni Fructus, antioxidant capacities and Hunter's colors values of Comi Fructus powder (CFP) were evaluated as functions of the particle size, extraction solvents and extraction time. The antioxidant capacity was determined in terms of the total phenolic contents (TPC), total anthocyanin contents (TAC), and DPPH radical scavenging activity. CFP was classified as CFP-1 (25-45 mesh), CFP-2 (45-60 mesh), CFP-3 (60-100 mesh), and CFP-4 (>100 mesh). The antioxidant capacities and extraction yield, depending on the particle size of CFP, were the highest for CFP-2, with an extraction yield of $5.45 \%$, a-value of 30.71 , TPC of $3.52 \mu$ M GAE, TAC of $19.20 \mathrm{mg} / \mathrm{L}$. Depending on the extraction solvent, the extraction yields were the highest to $60 \%$ ethanol, at $9.15 \%(p<0.05)$; further, antioxidant capacities were that TAC was highest to $90 \% \mathrm{EtOH}$ with $12.18 \mathrm{\mu M}$ GAE, whereas DPPH was not significantly different $(\mathbf{p}<0.05)$. Depending on the extraction time, extraction yields were highest $(4.43 \%)$ for extraction in $3 \mathrm{~h}$, and. TAC and DPPH were not significantly different $(p<0.05)$. Therefore, the antioxidant capacity of CFP was excellent with 45-60 mesh (CFP-2), an extraction solvent of $90 \% \mathrm{EtOH}$, and extraction time of $3 \mathrm{~h}$. The findings establish the proper extraction conditions of Corni Fructus for its use as a functional material.
\end{abstract}

Key words : antioxidant capacity, Comi Fructus, extraction condition, particle size

\section{서 론}

산수유(Cornus officinalis)는 층층나무과에 속하는 약용 식물로서 내한성이 강하고 음지에서도 개화 할 수 있을 정도로 이식력이 강하며, 겨울에 꽃봉오리가 피기 시작하 여 3,4월에 노란 꽃이 만개한다(1). 산수유 열매(Corni Fructus)는 $1.5 \mathrm{~cm}$ 이내의 장추원형의 모양으로 늦은 가을과 초겨울에 붉은색을 띠며, 종자에는 렉틴이라는 독성이 있

*Corresponding author. E-mail : kchung@knu.ac.kr Phone : 82-53-950-5778, Fax : 82-53-950-6772

Received 14 August 2018; Revised 27 September 2018; Accepted 1 October 2018.

Copyright (c) The Korean Society of Food Preservation. All rights reserved.
어 제핵 후 과실을 건조시켜 주로 약용으로 이용되어 왔다 (2). 산수유 열매의 주요 성분으로는 안토시아닌(anthocyanin), 우르솔산(ursolic acid), 주석산(tartaric acid), 사과산(malic acid) 외에 모로니사이드(morroniside), 로가닌(loganin), 스 웨로사이드(sweroside), 메틸 모로니사이드(methyl morroniside) 등의 배당체가 있으며(3) 항당뇨(4), 기억력 증진(5), 산화적 스트레스에 의한 신경세포 독성을 예방하는 효능이 있는 것으로 알려져 있다(6). 식물성 시료는 유기용매(물, 에탄 올, 메탄올)로 추출 하였을 때, 안토시아닌(anthocyanin), 탄 닌(tannin), 폴리페놀(polyphenol)등의 성분이 주로 추출되 며, 비극성 용매(헥산, 에테르, 클로로포름)로 추출 하였을 때는 테르펜노이드(terpenoids), 플라보노이드(flavonoids) 등의 성분이 추출된다(7). 산수유 열매의 물 추출물은 항히 스타민, 항아세틸콜린 및 항바륨작용, 황색포도상구균을 
억제하며, 메탄올 추출물과 에틸분획물은 피부질환 치료제 및 미백효과에 대한 연구가 보고되었고(8), 에탄올 추출물 은 항알레르기, 여드름균 억제 등에 효능이 있다(9,10). 국내 연구로는 산수유 추출물의 항균 및 항산화 활성(11), 함유된 항암물질의 정제 및 특성(12), 산수유의 유리자유기에 의한 간 손상 보호효과 및 기전에 대한 연구(13) 등이 있다.

본 연구에서는 산수유의 기능성 소재화에 필요한 적정 추출 조건을 구명하기 위하여 분말 입도, 추출 용매와 추출 시간에 따른 색도와 항산화능을 조사하여 보고하는 바이 다.

\section{재료 및 방법}

\section{실험재료}

본 실험에 사용된 산수유(Corni Fructus)는 경북대학교 교내에서 채취하여 정선 및 수세 작업을 거쳐 물기를 제거 후 음지, 상온에서 자연건조 하였다(수분 함량 $11 \%$ ). 건조 된 산수유를 막자사발로 마쇄하여 나온 산수유 분말(Corni Fructus powder, CFP)을 표준체(Chung Gye Industrial Co., Osan, Korea)를 이용하여 CFP-1(25-45 mesh), CFP-2 (45-60 mesh), CFP-3(60-100 mesh), CFP-4(>100 mesh)로 분류하였 다(Fig. 1).
(A)

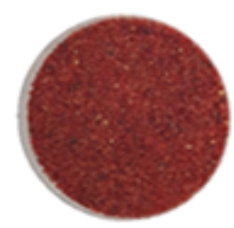

CFP-1

(C)

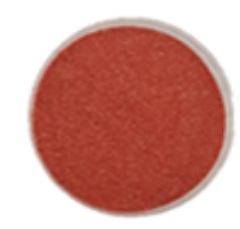

CFP-3
(B)

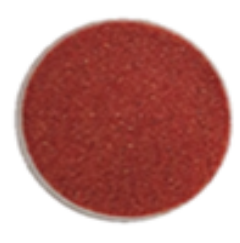

CFP-2

(D)

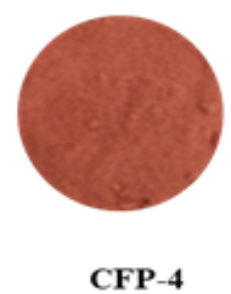

Fig. 1. Photos of Corni Fructus powders depending on particle size. A, 25-45 mesh; B, 45-60 mesh; C, 60-100 mesh; D, >100 mesh.

\section{추출 조건}

분말 입도에 따른 산수유의 추출 조건은 산수유 분말 CFP-1, CFP-2, CFP-3, 및 CFP-4 각각에 메탄올을 시료 무게 의 10 배에 해당하는 양을 가하여 12 시간 정치추출 후 여과 (Whatman No.2)하여 여액을 시액으로 사용하였다. 추출
용매에 따른 산수유의 추출 조건은 산수유 분말 CFP-2에 물, $30 \%$ 에탄올, $60 \%$ 에탄올, $90 \%$ 에탄올, 메탄올 추출 용매를 시료 무게 10 배에 해당하는 양을 각각 가하여 12 시 간 정치추출 후 여과(Whatman No.2)하여 여액을 시액으로 사용하였다. 추출 시간에 따른 산수유의 추출 조건은 산수 유 분말 CFP-2에 추출 용매 $90 \%$ 에탄올을 시료 무게 10 배에 해당하는 양을 가하여 추출 시간에 따라 3시간, 6시간, 9시 간 12 시간, 24 시간 동안 각각 정치추출 후 여과(Whatman No.2)하여 여액을 시액으로 사용하였다.

\section{추출 수율}

추출 수율은 추출 조건에 따라 얻은 시액을 사용하였으 며, 건조오븐을 이용하여 $105^{\circ} \mathrm{C}$ 상압가열건조법(14)으로 항량이 될 때까지 건조한 후 추출액 조제에 사용한 원료 건물량에 대한 고형분 수율(\%)로 나타내었다.

\section{색 도}

산수유 분말 CFP-1, CFP-2, CFP-3 및 CFP-4의 시료 표면 을 표준 백색판 $(\mathrm{L}=99.50, \mathrm{a}=-0.11, \mathrm{~b}=-0.13)$ 으로 보정한 후 Hunter 색차계(CM-700d, Minolta Co., Osaka, Japan)를 이용 하여 명도(L-value, lightness), 적색도(a-value, redness) 및 황색도(b-value, yellowness) 값을 10회 측정하여 나타내었 다.

\section{총 폴리페놀 함량}

총 폴리페놀 함량은 Folin-Ciocalteu procedure(15)을 변형 하여 측정하였다. 추출 조건에 따라 얻은 시액을 분석용 시료로 사용하였다. 분석용 시료 $100 \mu \mathrm{L}$ 에 $2 \mathrm{~N}$ Folin-Ciocalteu regent $50 \mu \mathrm{L}$ 와 $20 \%$ sodium carbonate 300 $\mu \mathrm{L}$ 를 가하여 실온에서 15 분간 반응 후 증류수 $1 \mathrm{~mL}$ 를 가하 여 원심분리 $(1,250 \mathrm{rpm}, 5 \mathrm{~min})$ 하고 얻은 상등액을 $725 \mathrm{~nm}$ 에서 흡광도를 측정하였다. 총 폴리페놀 함량은 gallic acid 를 이용하여 표준곡선을 작성하였으며 $\mu \mathrm{M} \mathrm{GAE}$ 로 나타내 었다.

\section{총 안토시아닌 함량}

총 안토시아닌 함량은 $\mathrm{pH}$ differential 방법(16)을 이용하 여 측정하였다. 추출 조건에 따라 얻은 시액을 분석용 시료 로 사용하였다. 분석용 시료 $0.5 \mathrm{~mL}$ 에 $0.025 \mathrm{M}$ potassium

Toal anthocyanin contents $(\mathrm{mg} / \mathrm{L})=\frac{\mathrm{A} \times \mathrm{MW} \times \mathrm{D} \times 1,000}{\varepsilon \times 1}$

$\mathrm{A}=\left(\mathrm{A}_{530 \mathrm{~nm}}-\mathrm{A}_{700 \mathrm{~nm}}\right) \mathrm{pH} \quad 1.0-\left(\mathrm{A}_{530} \mathrm{~nm}-\mathrm{A}_{700 \mathrm{~nm}}\right)_{\mathrm{pH}} 4.5$

$\mathrm{D}$ : dilution rate

$\varepsilon$ : molar absorption coefficient $=26,900$

$\mathrm{MW}($ molecular weight $)=449.2 \mathrm{~g} / \mathrm{mol}$ 
chloride buffer( $\mathrm{pH}$ 1.0) $0.5 \mathrm{~mL}$ 와 $0.4 \mathrm{M}$ sodium acetate buffer(pH 4.5) $0.5 \mathrm{~mL}$ 를 각각 가하여 반응시킨 용액을 530 $\mathrm{nm}$ 와 $700 \mathrm{~nm}$ 에서 각각의 흡광도를 측정하였으며, 아래 식에 따라 계산하여 나타내었다.

\section{$\mathrm{DPPH}$ 라디칼 소거능}

$\mathrm{DPPH}$ 라디칼 소거능은 Blois 등(17)의 방법을 변형한 방법으로 측정하였다. 추출 조건에 따라 얻은 시액을 분석 용 시료로 사용하였다. 분석용 시료 $20 \mu \mathrm{L}$ 과 $200 \mu \mathrm{M} \mathrm{DPPH}$ 시액 $180 \mu \mathrm{L}$ 를 혼합한 후 30 분간 암실에서 방치하고 UV/Vis spectrometer(UV-1601, Shimadzu CO., Kyoto, Japan)를 이용하여 $517 \mathrm{~nm}$ 에서 측정하였다. DPPH 라디칼 소거능은 gallic acid를 이용하여 표준곡선을 작성하였으며 $\mu \mathrm{M}$ GAE로 나타내었다.

\section{통계 분석}

모든 실험은 3회 반복 수행하여 평균치와 표준편차로 나타내었다. 실험군 간의 상관성 분석은 SAS 9.4(Statistic Analysis System, SAS Institute Inc, Cary, NC, USA)를 이용 하여 분산분석(ANOVA)을 수행한 후 Duncan's multiple range test를 이용하여 시료간의 유의적인 차이를 검증하였 다 $(\mathrm{p}<0.05)$.

\section{결과 및 고찰}

\section{분말 입도에 따른 산수유의 색도}

분말 입도에 따른 산수유 시료는 Fig. 1에 나타냈으며, 색도 L 값(lightness), $\mathrm{a}$ 값(redness), $\mathrm{b}$ 값(yellowness)은 Table 1 에 나타내었다. 산수유 분말 명도 L값은 CFP-4(47.29), CFP-3(36.68), CFP-2(35.57), CFP-1(32.53)로 분말 입도 크 기가 작아질수록 명도 $\mathrm{L}$ 값이 증가하였다 $(\mathrm{p}<0.05)$. 적색도 $\mathrm{a}$ 값은 CFP-2 시료가 30.71로 가장 높은 값을 나타냈으며, CFP-3(29.57), CFP-1(27.89), CFP-4(25.48) 순으로 나타났 으며 $(\mathrm{p}<0.05)$, Lee 등(18)의 연구에 따르면 분말의 적색도 a 값이 높을수록 안토시아닌 함량이 높다고 하였다. 황색도

Table 1. Hunter's color values of Corni Fructus powders depending on different particle size

\begin{tabular}{ccccc}
\hline & CFP-1 $^{1)}$ & CFP-2 & CFP-3 & CFP-4 \\
\hline L $^{2)}$ & $32.53 \pm 0.54^{\mathrm{d} 3)}$ & $35.57 \pm 0.02^{\mathrm{c}}$ & $36.68 \pm 0.09^{\mathrm{b}}$ & $47.29 \pm 0.02^{\mathrm{a}}$ \\
a & $27.89 \pm 0.01^{\mathrm{c}}$ & $30.71 \pm 0.01^{\mathrm{a}}$ & $29.57 \pm 0.02^{\mathrm{b}}$ & $25.48 \pm 0.01^{\mathrm{d}}$ \\
$\mathrm{b}$ & $15.72 \pm 0.01^{\mathrm{d}}$ & $20.09 \pm 0.02^{\mathrm{b}}$ & $21.28 \pm 0.02^{\mathrm{a}}$ & $17.91 \pm 0.01^{\mathrm{c}}$ \\
\hline
\end{tabular}

${ }^{1)}$ CFP, Corni Fructus powders; CFP-1, 25-45 mesh; CFP-2, 45-60 mesh; CFP-3, 60-100 mesh; CFP-4, >100 mesh.

${ }^{2} \mathrm{~L}$, lightness (0-100); a, greenness-redness (-80-100); b, blueness-yellowness (-70-70).

${ }^{3)}$ Means $\pm \mathrm{SD}$ ( $\mathrm{n}=3$ ) within each row followed by the same letter are not significantly different $(\mathrm{p}<0.05)$. b 값은 CFP-1(15.72), CFP-2(20.09), CFP-3(21.28) 순으로 분 말 입도가 작아질수록 b 값이 증가하였으나, CFP-4는 17.91 로 감소하였다 $(\mathrm{p}<0.05)$. 분말 입도에 따라서 색도 $\mathrm{L}$ 값, $\mathrm{a}$ 값 및 $\mathrm{b}$ 값의 차이가 나타났으며, 적색도 $\mathrm{a}$ 값이 가장 높고 명도 L 값이 낮은 CFP-2 시료가 안토시아닌 함량도 높을 것으로 사료된다.

\section{분말 입도에 따른 산수유의 추출 수율 및 항산화능}

분말 입도에 따른 산수유 시료 각각에 추출용매 메탄올 을 시료 무게의 10 배에 해당하는 양을 가하여 12 시간 정치 추출 하여 제조한 시액의 추출 수율 및 항산화능은 Table 2에 나타내었다. 분말 입도에 따른 추출 수율은 CFP-2 시료 가 $5.45 \%$ 로 가장 높게 나타났으며, CFP-3(5.16\%), CFP-4(4.97\%), CFP-1(4.94\%) 순으로 나타났다(p<0.05). 총 폴리페놀 함량은 2.53-3.55 $\mu \mathrm{M} \mathrm{GAE}$ 의 범위를 나타냈으며, CFP-2 및 CFP-4 시료에서 각각 $3.52 \mu \mathrm{M} \mathrm{GAE}$ 및 $3.55 \mu \mathrm{M}$ GAE로 CFP-1(2.53 $\mu \mathrm{M} \mathrm{GAE})$ 과 CFP-3(2.78 $\mu \mathrm{M} \mathrm{GAE})$ 보다 높게 나타났다 $(\mathrm{p}<0.05)$. 분말 입도가 가장 작은 CFP-4 시료 는 분말 입도가 가장 큰 CFP-1 시료보다 총 폴리페놀 함량 이 1.4 배 높게 나타났으며, 감 껍질 분말의 입도가 작아질수 록 총 폴리페놀 함량이 높아진다는 보고와 유사하였다(19). 총 안토시아닌 함량은 13.51-19.20 mg/L의 범위로 CFP-2 시료가 $19.20 \mathrm{mg} / \mathrm{L}$ 로 가장 높게 나타났으며, CFP-4(18.24 $\mathrm{mg} / \mathrm{L})$, CFP-3(15.53 mg/L), CFP-1(13.51 mg/L) 순으로 나타 내었다(p<0.05). DPPH 라디칼 소거능은 1.49-2.14 $\mu \mathrm{M} \mathrm{GAE}$ 의 범위로 CFP-4의 시료가 $2.14 \mathrm{\mu M} \mathrm{GAE}$ 로 가장 높게 나타 났으며, CFP-2(2.02 $\mu \mathrm{M}$ GAE), CFP-3(1.82 $\mu \mathrm{M}$ GAE), $\mathrm{CFP}-1(1.49 \mu \mathrm{M} \mathrm{GAE})$ 순으로 나타내었다(p<0.05). 분말 입 도별 추출 수율, 총 폴리페놀 함량, 총 안토시아닌 함량은 분말 입도 CFP-2에서 가장 높았고, DPPH 라디칼 소거활성 도 높게 나타나 분말 입도 45-60 mesh(CFP-2)가 적합하다고 사료된다.

Table 2. Extraction yields and antioxidant capacities of methanol extract of Corni Fructus powders depending on different particle size

\begin{tabular}{ccccc}
\hline & CFP-1 $^{1)}$ & CFP-2 & CFP-3 & CFP-4 \\
\hline $\begin{array}{c}\text { Extraction yield } \\
(\%)\end{array}$ & $4.94 \pm 0.08^{\mathrm{c} 4)}$ & $5.45 \pm 0.06^{\mathrm{a}}$ & $5.16 \pm 0.03^{\mathrm{b}}$ & $4.97 \pm 0.19^{\mathrm{bc}}$ \\
$\begin{array}{c}\mathrm{TPC})^{2)} \\
(\mu \mathrm{M} \mathrm{GAE})\end{array}$ & $2.53 \pm 0.03^{\mathrm{c}}$ & $3.52 \pm 0.05^{\mathrm{a}}$ & $2.78 \pm 0.01^{\mathrm{b}}$ & $3.55 \pm 0.04^{\mathrm{a}}$ \\
$\begin{array}{c}\mathrm{TAC} \mathrm{C}^{3)} \\
(\mathrm{mg} / \mathrm{L})\end{array}$ & $13.51 \pm 0.32^{\mathrm{d}}$ & $19.20 \pm 0.23^{\mathrm{a}}$ & $15.53 \pm 0.10^{\mathrm{c}}$ & $18.24 \pm 0.39^{\mathrm{b}}$ \\
$\begin{array}{c}\mathrm{DPPH} \\
(\mu \mathrm{M} \mathrm{GAE})\end{array}$ & $1.49 \pm 0.01^{\mathrm{d}}$ & $2.02 \pm 0.02^{\mathrm{b}}$ & $1.82 \pm 0.01^{\mathrm{c}}$ & $2.14 \pm 0.02^{\mathrm{a}}$ \\
\hline
\end{tabular}

${ }^{1)}$ CFP, Corni Fructus powders; CFP-1, 25-45 mesh; CFP-2, 45-60 mesh; CFP-3, 60-100 mesh; CFP-4, >100 mesh.

${ }^{2)} \mathrm{TPC}$, total phenolic contents.

${ }^{3)} \mathrm{TAC}$, total anthocyanin contents.

${ }^{4}$ Means $\pm \mathrm{SD}$ ( $\mathrm{n}=3$ ) within each row followed by the same letter are not significantly different $(p<0.05)$. 


\section{추출 용매에 따른 산수유의 추출 수율 및 항산화능}

산수유 분말 입도 45-60 mesh(CFP-2)의 시료를 추출 용 매에 따라 시료 무게의 10 배에 해당하는 양을 가하여 12 시 간 정치 추출 하여 제조한 시액의 추출수율 및 항산화능을 Table 3에 나타내었다. 추출 용매에 따른 추출 수율은 $60 \%$ 에탄올일 때 $9.15 \%$ 로 가장 높게 나타났으며, $90 \%$ 에탄올 (7.95\%), $30 \%$ 에탄올(7.61\%), 메탄올(7.37\%), 물(7.11\%) 추 출물 순으로 나타났다 $(\mathrm{p}<0.05)$. 오미자를 추출 용매에 따라 추출 하였을 때 유기용매 추출물이 물 추출물 보다 수율이 높았으며(20), 본 연구의 결과와 유사 하였다. 총 폴리페놀 함량은 3.34-5.20 $\mu \mathrm{M} \mathrm{GAE}$ 의 범위로 $30 \%$ 에탄올과 $60 \%$ 에탄올이 각각 $5.20 \mu \mathrm{M} \mathrm{GAE}$ 및 $5.14 \mu \mathrm{M} \mathrm{GAE}$ 로 가장 높았 다 $(\mathrm{p}<0.05)$. 추출 조건에 따른 산수유 열매의 생리활성 연구 에서 $30 \%$ 에탄올, $60 \%$ 에탄올, 물, $90 \%$ 에탄올 순으로 페놀성 화합물의 물질을 많이 포함된다고 하였으며(21), 본 연구의 결과와 유사하였다. 총 안토시아닌 함량은 $1.68-15.27 \mathrm{mg} / \mathrm{L}$ 의 범위로 메탄올로 추출 하였을 때 15.27 $\mathrm{mg} / \mathrm{L}$ 로 가장 높게 나타났고, $90 \%$ 에탄올 $(12.18 \mathrm{mg} / \mathrm{L}), 60 \%$ 에탄올 $(11.38 \mathrm{mg} / \mathrm{L}), 30 \%$ 에탄올 $(6.95 \mathrm{mg} / \mathrm{L})$ 및 물 $(1.68$ $\mathrm{mg} / \mathrm{L})$ 의 순서로 유기용매의 농도가 낮아질수록 안토시아 닌 함량은 낮게 나타났다. 구기자 추출물의 에탄올 농도가 $20 \%$ 이상일 때 에탄올 농도가 증가할수록 안토시아닌 함량 은 비례적으로 증가한다고 보고하였으며(22), 본 실험에서 도 에탄올 농도가 증가할수록 안토시아닌 함량이 유의적으 로 증가하여 앞선 결과와 유사하였다. DPPH 라디칼 소거능 의 범위는 2.71-3.96 $\mu \mathrm{M} \mathrm{GAE}$ 의 범위로 $30 \%$ 에탄올과 메탄 올로 추출 했을 때 각각 $3.95 \mu \mathrm{M} \mathrm{GAE}$ 및 $3.96 \mu \mathrm{M} \mathrm{GAE}$ 로 높게 나타났다. 추출 용매에 따른 산수유의 추출물 생리활 성에서 추출 용매에 따라 DPPH 라디칼 소거능의 활성 차이 가 뚜렷하게 나타나지 않았다고 보고하였으며(21), 본 연구 결과와 유사하였다. 추출 용매에 따른 항산화능에 대한 분 석 결과 기능성 소재화를 위한 목적으로 안토시아닌이 많이

Table 3. Extraction yields and antioxidant capacities of Corni Fructus powders-2 (CFP-2) depending on solvent types

\begin{tabular}{|c|c|c|c|c|c|}
\hline & \multicolumn{4}{|c|}{ Ethanol (\%) } & \multirow{2}{*}{$\begin{array}{c}\begin{array}{c}\text { Methanol } \\
(\%)\end{array} \\
100\end{array}$} \\
\hline & 0 & 30 & 60 & 90 & \\
\hline $\begin{array}{l}\text { Extraction yield } \\
\qquad(\%)\end{array}$ & $7.11 \pm 0.08^{\mathrm{d} 3)}$ & $7.61 \pm 0.14^{\mathrm{bc}}$ & $9.15 \pm 0.15^{\mathrm{a}}$ & $7.95 \pm 0.06^{b}$ & $7.37 \pm 0.16^{\mathrm{cd}}$ \\
\hline $\begin{array}{c}\mathrm{TPC}^{1)} \\
(\mu \mathrm{M} \text { GAE })\end{array}$ & $3.34 \pm 0.03^{\mathrm{c}}$ & $5.20 \pm 0.05^{\mathrm{a}}$ & $5.14 \pm 0.02^{\mathrm{a}}$ & $4.09 \pm 0.02^{\mathrm{b}}$ & $4.11 \pm 0.02^{\mathrm{b}}$ \\
\hline $\begin{array}{l}\mathrm{TAC}^{2)} \\
(\mathrm{mg} / \mathrm{L})\end{array}$ & $1.68 \pm 0.39^{\mathrm{e}}$ & $6.95 \pm 0.35^{\mathrm{d}}$ & $11.38 \pm 0.69^{c}$ & $12.18 \pm 1.44^{b}$ & $15.27 \pm 0.91^{\mathrm{a}}$ \\
\hline $\begin{array}{c}\mathrm{DPPH} \\
(\mu \mathrm{M} \mathrm{GAE})\end{array}$ & $2.71 \pm 0.02^{\mathrm{c}}$ & $3.95 \pm 0.14^{\mathrm{a}}$ & $3.61 \pm 0.16^{b}$ & $3.59 \pm 0.06^{b}$ & $3.96 \pm 0.38^{\mathrm{a}}$ \\
\hline
\end{tabular}

${ }^{1)}$ TPC, total phenolic contents.

${ }^{2)} \mathrm{TAC}$, total anthocyanin contents.

${ }^{3)}$ Means \pm SD ( $n=3$ ) within each row followed by the same letter are not significantly different $(\mathrm{p}<0.05)$
추출되는 $90 \%$ 에탄올이 추출용매로 적합하다고 사료된다.

\section{추출 시간에 따른 산수유의 추출 수율 및 항산화능}

산수유 분말 입도 $45-60$ mesh(CFP-2)에 $90 \%$ 에탄올을 시료 무게의 10 배에 해당하는 양을 가하여 추출 시간에 따라 제조한 시액의 추출 수율과 항산화능을 Fig. 2에 나타 내었다. 추출 수율은 추출 시간에 따라 3 시간(4.43\%), 12 시 간(4.20\%), 24시간(4.10\%), 9시간(4.09\%), 6시간(4.00\%) 순 으로 나타났다( $<<0.05)$. 총 폴리페놀 함량은 6.67-7.39 $\mu \mathrm{M}$ $\mathrm{GAE}$ 의 범위로, 3 시간 추출 시 $7.32 \mu \mathrm{M} \mathrm{GAE}$ 로 가장 높았다 $(\mathrm{p}<0.05)$. 건조 구기자의 에탄올 추출물의 농도가 $60 \%$ 이상 일 때 추출 시간이 증가할수록 총 폴리페놀 함량이 감소된 다고 보고하였으며(22), 본 연구 결과와 유사하였다. 총 안 토시아닌 함량은 추출 시간에 따라 $15.18-16.87 \mathrm{mg} / \mathrm{L}$ 의 범 위로 24 시간 추출할 때 $16.87 \mathrm{mg} / \mathrm{L}$ 로 가장 높았으나 다른 추출 시간과의 함량 차이가 없었다 $(\mathrm{p}<0.05)$. 구기자 추출물 의 최적 항산화 추출 조건 모니터링에서 추출 시간이 1 시간 이상 일 때 안토시아닌의 함량 변화가 거의 없었다고 보고 하였고(23), 본 연구에서는 24시간 추출할 때 안토시아닌 함량이 가장 높았으나 추출 시간에 따라 안토시아닌 함량

(A)

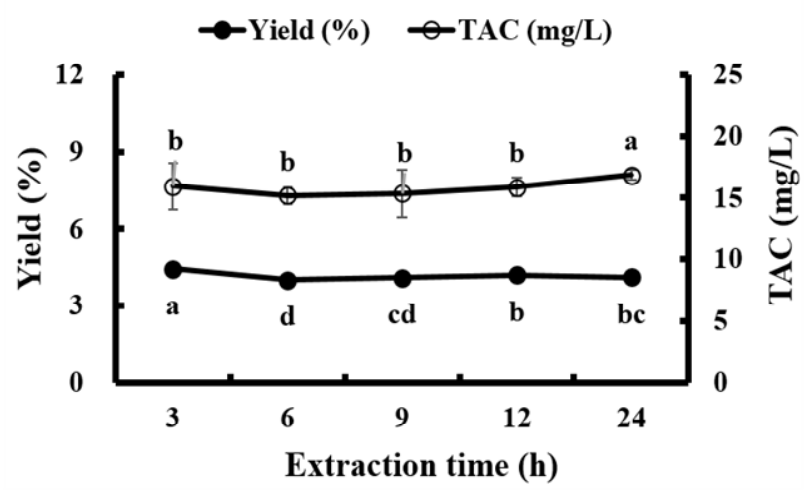

(B)

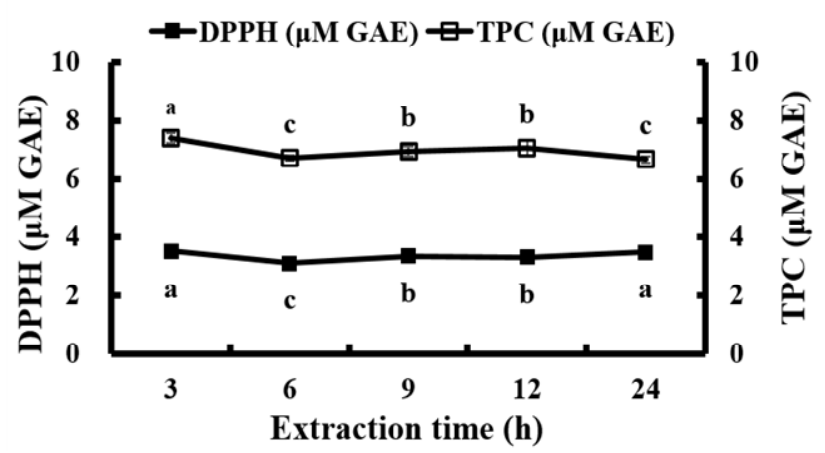

Fig. 2. Extraction yields and antioxidant capacities of Corni Fructus powders-2 (CFP-2) with 90\% ethanol depending on extraction time. O. Extraction yield; $\bigcirc$, total anthocyanin contents; $\square$, DPPH; $\square$, total Phenolic contents.

Values represent the mean $\pm \mathrm{SD}(\mathrm{n}=3)$. Means with different letters above a bar are significantly different at $\mathrm{p}<0.05$. 
차이가 크게 나타나지 않았으므로 3시간 추출을 하였을 때 안토시아닌 성분이 충분히 추출되었음을 알 수 있었다. $\mathrm{DPPH}$ 라디칼 소거능은 3.08-3.50 $\mathrm{MM} \mathrm{GAE}$ 의 범위를 가졌 으며, 3시간 추출할 때 $3.50 \mu \mathrm{M} \mathrm{GAE}$ 로 가장 높았다 $(\mathrm{p}<0.05)$. 산수유나무의 추출 시간에 따른 추출물의 항산화 및 항균활성에서 산수유 열매를 에탄올 용매로 시간별로 추출 하였을 때 3-24시간까지 DPPH 라디칼 소거능이 큰 차이를 보이지 않았다고 보고하였고(24), 삼백초를 추출 용매에 따라 추출하였을 때 추출 시간이 4시간 이상 증가할 수록 항산화 성분 함량 및 항산화 활성이 비례하여 증가하 지 않았다고 보고하였으며(25), 이는 본 연구결과와 유사하 였다. 추출 시간에 따른 항산화능에 대한 분석 결과 추출 시간이 3 시간 이후 뚜렷한 차이가 나타나지 않으므로 추출 시간은 3 시간이 적합하다고 사료된다.

\section{요 약}

본 연구에서는 산수유(Corni Fructus)의 기능성 소재화를 위한 적정 추출 조건을 찾아내기 위하여, 분말 입도 크기 (CFP-1, CFP-2, CFP-3, CFP-4), 추출 용매(물, 에탄올, 메탄 올)의 종류, 추출 용매 농도(물, $30 \%$ 에탄올, $60 \%$ 에탄올, $90 \%$ 에탄올, 메탄올) 및 추출 시간 $(3,6,912,24$ 시간)을 달리하여 추출 수율, 색도 및 항산화능(TPC, TAC, DPPH 라디칼 소거능)을 조사하였다. 분말 입도 CFP-2(45-60 mesh)는 추출 수율(5.45\%), 적색도(30.71) 및 항산화능 $\mathrm{TPC}(3.52 \mu \mathrm{M} \mathrm{GAE})$ 와 $\mathrm{TAC}(19.20 \mu \mathrm{M} \mathrm{GAE})$ 가 가장 높았다 $(\mathrm{p}<0.05)$. 추출 용매에 따라 $60 \%$ 에탄올로 추출하였을 때 추출 수율은 $9.15 \%$ 로 가장 높았고(p<0.05), $\mathrm{TAC}$ 는 $90 \%$ 에탄올로 추출할 때 $12.18 \mu \mathrm{M} \mathrm{GAE}$ 로 가장 높았으며 $(\mathrm{p}<0.05), \mathrm{DPPH}$ 라디칼 소거능은 차이가 없었다 $(\mathrm{p}<0.05)$. 추출 시간에 따라 추출 수율은 3 시간 추출 시 $4.43 \%$ 로 가장 높았으며 $(\mathrm{p}<0.05)$, 추출 시간에 따라 TAC, DPPH 라디칼 소거능은 차이가 없었다 $(\mathrm{p}<0.05)$. 따라서 산수유의 적정 추 출 조건은 분말입도 45-60 mesh(CFP-2), 추출 용매 90\% 에탄올, 추출 시간 3 시간 일 때 추출 수율, 색도 및 항산화능 이 우수하였으며, 이를 이용하여 기능성 소재로 활용 가능 하다고 판단된다.

\section{References}

1. Park EB, Kim HS, Shin SY, Ji IA, Kim JH, Kim SG, Yoo BH, Kim BW, Kwak I, Kim MM, Chung KT (2012) Antioxidative activity of Cornus officinalis extracts obtained by four different extraction techniques. J Life Sci, 22, 1507-1514
2. Lee MH, Kim JM, Park EJ (2011) Antioxidant and antigenotoxic effects of Sansuyu fruit (Corni fructus) extracted with water at different temperatures. J Korean Soc Food Sci Nutr, 40, 149-155

3. Lee WB, Jung HS, Kwon J, Oh CH, Lee KG (2002) Immunoregulatory action of Cornus officinalis Sieb. et Zucc. Korean J Orient Physiol Pathol, 16, 267-271

4. Kim YD, Kim HK, Kim KJ (2003) Analysis of nutritional components of Cornus officinalis. J Korean Soc Food Sci Nutr, 32, 785-789

5. Kim CS, Jang DS, Kim JH, Lee GY, Lee YM, Kim YS, Kim JS (2008) Inhibitory effects of the seeds of Cornus officinalis on AGEs formation and AGEs-induced protein cross-linking. Korean J Pharmacogn, 39, 249-254

6. Lee KY, Sung SH, Kim SH, Jang YP, Oh TH, Kim YC (2009) Cognitive-enhancing activity of loganin isolated from Cornus officinalis in scopolamine-induced amnesic mice. Arch Pharmacal Res, 32, 677-683

7. Azmir J, Zaidul ISM, Rahman MM, Sharif KM, Mohamed A, Sahena F, Jahurul MHA, Ghafoor K, Norulaini NAN, Omar AKM (2013) Techniques for extraction of bioactive compounds from plant materials: A review. J Food Eng, 4, 426-436

8. Choi WY, Chun HJ, Lee JH, Baek SH (2003) Effects of methanol extract from Corni fructus on melanogenesis. Korean J Pharmacogn, 34, 70-74

9. Choi JY, Song SY, Lee HH (2015) Antibacterial and anti-inflammatory activity of Corni Fructus ethanol extract in Propionibacterium acnes. Korean J Aesthetic Cosmetol, 13, 623-630

10. Seo YB, Kil GJ, Lee YG, Lee YC (2002) Study on the effects of Corni Fructus about the anti-allergic action. Korea J Herbology, 17, 1-12

11. Seo KI, Lee SW, Yang KH (1999) Antimicrobial and antioxidative activity of Corni Fructus extracts. Korean J Food Preserv, 6, 99-103

12. Kim BH, Park KW, Kim JY, Jeong IY, Yang GH, Cho YS, Yee ST, Seo KI (2004) Purification and characterization of anticarcinogenic compound from Corni fructus. Korean J Food Sci Technol, 36, 1001-1007

13. Ha KT, Kim YM, Kim CH, Kim DW, Choi DY, Kim JK (2008) Study on the protective effect of Corni fructus against free radical mediated liver damage. Korean $\mathrm{J}$ Orient Physiol Pathol, 22, 82-88

14. AOAC (1990) Official methods of analysis. $15^{\text {th }} \mathrm{ed}$, Association of official analytical chemists, Washington DC, USA, p 1010-1011 
15. Slinkard K, Singleton VL (1977) Total phenol analysis: Automation and comparison with manual methods. Am J Enol Vitic, 28, 49-55

16. Lee J, Durst RW, Wrolstad RE (2005) Determination of total monomeric anthocyanin pigment content of fruit juices, beverages, natural colorants, and wines by the $\mathrm{pH}$ differential method: Collaborative study. J AOAC Int, 88, 1269-1278

17. Blois MS (1958) Antioxidant determinations by the use of a stable free radical. Nature, 181, 1199-1200

18. Lee HJ, Sung JH, Choi JY, Cho JS, Lee YM, Chung HS, Moon KD (2016) Evaluation of the quality characteristics in Omija (Schizandara chinensis Baillon) powder tea. Korean J Food Sci Technol, 48, 42-47

19. Hwang IW, Jeong MC, Chung SK (2011) The physicochemical properties and the antioxidant activities of persimmon peel powders with different particle sizes. J Korean Soc Appl Biol Chem, 54, 442-446

20. Nam SY, Lee JY, Ko JS, Kim JB, Jang HH, Kim HR, Lee YM (2014) Changes in antioxidant and antimicrobial activities of Schizandra chinensis Baillon under different solvent extraction. Korean J Int Agric, 26, 513-518

21. Lee HJ, Do JR, Kwon JH, Kim HK (2012) Physiological properties of Corni Fructus extracts based on their extraction condition. Korean J Food Preserv, 19, 271-277

22. Lee GD (2016) Monitoring of antioxidant activities with dried Gugija (lycium chinensis mill) extraction. Korean J Food Preserv, 23, 859-865

23. Kim HY, Lee GD (2017) Monitoring for optimum antioxidant extraction condition of Gugija (lycium chinensis mill) extract. KOCS, 34, 451-460

24. Yoo BR (2015) Antioxidant and antimicrobial activities of extracts from different parts of Cornus officinalis according to extraction time. MS Thesis, Seoul National University of Science and Technology, Korea, 1-53

25. Kim SK, Ban SY, Kim JS, Chung SK (2005) Change of antioxidant activity and antioxidant compounds in Saururus chinensis by extraction conditions. J Korean Soc Appl Biol Chem, 48, 89-92 